\title{
Pengaruh Kinerja Lingkungan, Ukuran Perusahaan, Profitabilitas dan Pengungkapan Emisi Karbon
}

\author{
Ni Putu Eka Dewayani ${ }^{1}$ \\ Fakultas Ekonomi dan Bisnis \\ Universitas Udayana, Indonesia
}

\author{
Ni Made Dwi Ratnadi ${ }^{2}$ \\ Fakultas Ekonomi dan Bisnis \\ Universitas Udayana, Indonesia
}

\begin{abstract}
Surel : ekadwyn97@gmail.com
ABSTRAK

Penelitian ini bertujuan untuk membuktikan secara empiris pengaruh kinerja lingkungan, ukuran perusahaan dan profitabilitas pada pengungkapan emisi karbon yang dilakukan pada perusahaan non keuangan yang terdaftar di Bursa Efek Indonesia. Populasi dalam penelitian ini adalah perusahaan non keuangan yang terdaftar di Bursa Efek Indonesia pada tahun 2017 dan 2018. Penentuan sampel dalam penelitian ini menggunakan teknik purposive sampling yang menghasilkan 112 perusahaan observasi. Teknik analisis data yang digunakan yaitu analisis regresi linear berganda. Berdasarkan hasil analisis menunjukkan bahwa ukuran perusahaan berpengaruh positif pada pengungkapan emisi karbon, hal ini menunjukkan apabila semakin besar ukuran perusahaan maka pengungkapan emisi karbon yang dilakukan akan semakin tinggi. Kinerja lingkungan dan profitabilitas tidak berpengaruh pada pengungkapan emisi karbon.
\end{abstract}

Kata Kunci: Pengungkapan Emisi Karbon; Kinerja Lingkungan; Ukuran Perusahaan; Profitabilitas.

\section{Effect of Environmental Performance, Company Size, Profitability and Disclosure of Carbon Emissions}$$
\text { ABSTRACT }
$$

This study aims to examine empirically the influence of environmental performance, size, and profitability on carbon emission disclosure at non-financial companies listed on Indonesia Stock Exchange. Population used in this study in non-financial companies listed on Indonesia Stock Exchange on 2017 and 2018. The technique of determining sample using purposive sampling and obtained 112 observation companies. The research data analysis used linear regression analysis. Based on the results of the analysis found that size has a significant positive effect on carbon emission disclosure. This shows that if the size of the company increase, the amount of carbon emission disclosure increases. Environmental performance and profitability has no effect on carbon emission disclosure.
\end{abstract}

Keywords: Carbon Emission Disclosure; Enviromental Performance; Size; Profitability.



e-ISSN 2302-8556

Vol. 31 No. 4

Denpasar, April 2021

Hal. 836-850

DOI:

10.24843/EJA.2021.v31.i04.p04

PENGUTIPAN:

Dewayani, N.P.E., \& Rartnadi, N.M.D. (2021).

Pengaruh Kinerja

Lingkungan, Ukuran Perusahaan, Profitabilitas dan Pengungkapan Emisi Karbon. E-Jurnal Akuntansi, 31(4), 836-850

RIWAYAT ARTIKEL: Artikel Masuk: 19 September 2020 Artikel Diterima: 2 Januari 2021

Artikel dapat diakses : https://ojs.unud.ac.id/index.php/Akuntansi/index 


\section{PENDAHULUAN}

Arus globalisasi menuntut agar perusahaan mampu terus berkembang dan bersaing di kerasnya persaingan global. Agar dapat bertahan perusahaan perlu melakukan aktivitas yang bisa diterima masyarakat luas, salah satu cara yang dapat dilakukan perusahaan adalah dengan melakukan aktivitas yang tidak hanya berfokus pada keuntungan perusahaan saja tetapi juga harus berfokus pada masyarakat dan lingkungan sekitar. Pengungkapan emisi karbon merupakan salah satu bentuk pertanggungjawaban sosial dan moral perusahaan ke masyarakat yang merupakan bagian dari laporan tambahan yang telah dinyatakan dalam Pernyataan Standar Akuntansi Keuangan (PSAK) dalam upaya menurunkan emisi karbon dan menghadapi tekanan dari masyarakat untuk mengurangi dampak kerusakan lingkungan akibat aktivitas operasional perusahaan yang banyak menghasilkan emisi karbon.

Melalui Perpres No. 71 Tahun 2011 Tentang Penyelenggaraan Inventaris Gas Rumah Kaca Nasional dan Perpres No. 61 Tahun 2011 Tentang Rencana Aksi Nasional Penurunan Gas Rumah Kaca, Indonesia berkomitmen untuk mengurangi emisi karbon. Pasal 4 Perpres No. 61 Tahun 2011, menyebutkan bahwa perusahaan juga ikut andil dalam upaya penurunan GRK. Peraturan Presiden No. 61 Tahun 2011 mengenai Rencana Aksi Nasional Penurunan Emisi Gas Rumah Kaca yang mengatur pengurangan emisi karbon pada sektor industri, kehutanan dan lahan gambut, pertanian, energi transportasi pengolahan limbah dan kegiatan lainnya yang berpotensi menghasilan emisi karbon. Berikut merupakan tabel tingkat emisi karbon di Indonesia menurut jenis sektor penyebabnya dari tahun 2001 sampai 2017.

Tabel 1. Tingkat Emisi Karbon Menurut Jenis Sektor Tahun 2001-2017

\begin{tabular}{rrrrrrrrr}
\hline \multirow{2}{*}{ No } & Tahun & \multicolumn{3}{c}{ Sektor } & \multicolumn{3}{c}{ (Ribuan Ton CO2) } \\
\cline { 2 - 8 } & & Energi & IPPU & Pertanian & Limbah & FOLU & Kebakaran & Jumlah \\
& & & & & & & Hutan \\
\hline 1 & 2001 & 341,919 & 48,269 & 94,134 & 67,602 & 329,243 & 50,885 & 932,053 \\
2 & 2002 & 349,485 & 41,688 & 93,856 & 70,063 & 373,189 & 301,753 & $1,230,034$ \\
3 & 2003 & 378,050 & 41,402 & 94,863 & 73,061 & 328,958 & 132,075 & $1,048,410$ \\
4 & 2004 & 380,434 & 43,146 & 96,586 & 75,225 & 475,851 & 232,018 & $1,303,260$ \\
5 & 2005 & 376,988 & 42,296 & 98,492 & 77,216 & 439,638 & 258,887 & $1,293,516$ \\
6 & 2006 & 386,100 & 38,641 & 97,828 & 82,578 & 479,246 & 510,710 & $1,595,103$ \\
7 & 2007 & 402,989 & 35,919 & 101,487 & 83,933 & 553,803 & 62,747 & $1,240,878$ \\
8 & 2008 & 391,784 & 36,499 & 98,659 & 85,023 & 513,712 & 81,744 & $1,207,420$ \\
9 & 2009 & 405,653 & 37,546 & 102,956 & 89,326 & 620,566 & 299,920 & $1,555,967$ \\
10 & 2010 & 453,235 & 36,033 & 104,501 & 87,669 & 383,405 & 51,383 & $1,116,226$ \\
11 & 2011 & 507,357 & 35,910 & 103,161 & 91,853 & 427,310 & 189,026 & $1,354,617$ \\
12 & 2012 & 540,419 & 40,078 & 106,777 & 95,530 & 487,928 & 207,050 & $1,477,781$ \\
13 & 2013 & 496,030 & 39,110 & 106,814 & 100,515 & 402,252 & 205,076 & $1,349,797$ \\
14 & 2014 & 531,142 & 47,489 & 107,319 & 102,834 & 480,033 & 499,389 & $1,768,206$ \\
15 & 2015 & 536,306 & 49,297 & 111,830 & 106,061 & 766,194 & 802,870 & $2,372,559$ \\
16 & 2016 & 538,025 & 55,307 & 116,690 & 112,351 & 545,181 & 90,267 & $1,457,821$ \\
17 & 2017 & 558,890 & 55,395 & 121,686 & 120,191 & 282,098 & 12,513 & $1,150,772$ \\
\hline
\end{tabular}

Sumber : Kementrian Lingkungan Hidup dan Kehutanan, 2019 
Melalui regulasi ini pemerintah secara bersama-sama mengajak pelaku usaha untuk mengurangi emisi karbon yang ditunjukkan dengan melakukan pengungkapan emisi karbon. Perubahan iklim menjadi salah satu isu lingkungan terbesar beberapa tahun terakhir ini yang disebabkan karena adanya pemanasan global. Pada tahun 2018, karbon dioksida global adalah 407,8 bagian per juta (ppm), jumlah tersebut lebih tinggi dari tahun 2017 (CNN Indonesia, 2019). Di Indonesia praktik tersebut terjadi karena adanya berbagai kasus pencemaran lingkungan yang dilakukan oleh beberapa perusahaan baik disengaja maupun tidak disengaja, seperti tindakan pengundulan hutan, semakin meningkatnya limbah dan polusi, kualitas keamanan produk yang buruk, eksploitasi sumber daya yang berlebihan yang tidak dilanjuti dengan perbaikan lingkungan.

Berdasarkan Tabel 1, peningkatan emisi karbon di Indonesia rata-rata mengalami peningkatan yang disebabkan oleh beberapa jenis sektor diantaranya dari sektor energi, IPPU, pertanian, limbah, FOLU, dan kebakaran hutan. Emisi karbon yang bersumber dari penggunaan energi merupakan faktor penyumbang emisi terbesar, hal tersebut terjadi karena beberapa sektor dari perusahaan non keuangan yang dalam menjalankan aktivitas operasionalnya lebih banyak menggunakan energi, diantaranya perusahaan dari sektor transportasi, industri dasar dan kimia, aneka industri dan pertambangan. Peningkatan paling tinggi terjadi pada tahun 2015 yang disebabkan karena kebakaran hutan. Dari data tersebut dapat memberikan bukti bahwa adanya banyak sektor dan banyaknya aktivitas operasional perusahaan khususnya dari perusahaan non keuangan yang dalam menjalankan aktivitas operasionalnya banyak mengeluarkan emisi karbon sehingga perlu adanya tindakan yang dilakukan perusahaan salah satunya dengan melakukan pengungkaan emisi karbon.

Sebagai bentuk nyata komitmen Indonesia untuk mengurangi emisi karbon di bawah Persetuan Paris dalam Nationally Determined Contribution (NDC), Indonesia menyatakan untuk mengurangi emisi karbon sebesar 29 persen pada tahun 2030 dengan upaya sendiri dan sebesar 40 persen jika ada kerja sama internasional dari kondisi tanpa ada aksi. Implementasi NDC dimulai pada tahun 2020, untuk mencapai hal tersebut diperlukan adanya pemantauan yang terdiri dari pra-2020 yang dimulai dari tahun 2017 dan pasca 2020 yang dimulai pada tahun 2020 (Kementrian Lingkungan Hidup dan Kehutanan, 2018). Untuk mengurangi dampak lingkungan tersebut pemerintah secara bersamasama mengajak pelaku usaha mengurangi emisi karbon yang ditunjukkan dengan melakukan pengungkapan emisi karbon. Namun, sifatnya yang masih sukarela mejadikan tidak semua perusahaan melakukan pengungkapan emisi karbon.

Teori legitimasi menyatakan organisasi akan selalu berusaha untuk meyakinkan bahwa kegiatan yang mereka lakukan berada pada lingkup yang bisa diterima oleh masyarakat dan lingkungan tempat mereka beroperasi. Teori ini didasari oleh adanya kontrak sosial antara masyarakat dan perusahaan. Masyarakat menuntut agar perusahaan melaporkan kegiatan lingkungan mereka secara sukarela sehingga perusahaan akan melakukan kegiatan tersebut untuk medapat legitimasi dari masyarakat (Guthrie \& Parker, 1989). Kinerja lingkungan merupakan sistem manajemen lingkungan perusahaan dalam upaya perusahaan untuk ikut menjaga dan melestarikan lingkungan. Semakin baik kinerja 
lingkungan yang dilakukan oleh perusahaan maka perusahaan akan melakukan lebih banyak pengungkapan emisi karbon untuk mendapatkan legitimasi. Semakin besar ukuran perusahaan maka akan semakin besar pula perhatian masyarakat pada perusahaan tersebut sehingga perusahaan mendapat tekanan untuk melakukan lebih banyak pengungkapan emisi karbon.

Berdasarkan teori stakeholder menyatakan bahwa perusahaan dalam menjalankan usahanya tidak hanya beroperasi untuk kepentingan perusahaan saja tetepi harus memberikan manfaat kepada seluruh stakeholder-nya. Stakeholder memiliki kemampuan untuk mengendalikan perusahaan dalam hal menjalankan aktivitasnya termasuk dalam pengendalian keuangan untuk melakukan pengungkapan emisi karbon. Profitabilitas merupakan kemampuan perusahaan dalam menghasilkan laba. Tingkat profitabilitas yang didapat perusahaan akan berpengaruh terhadap pengungkapan emisi karbon yang dilakukan perusahaan, karena jika perusahan mendapat laba yang tinggi maka akan mampu membeli sumber daya alam maupun mesin yang digunakan untuk mengurangi kerusakan lingkungan sehingga keinginan stakeholder untuk melakukan lebih banyak pengungkapan emisi karbon akan cenderung lebih banyak terjadi. Penelitian ini menggunakan tiga variabel yang memiliki hubungan saling keterkaitan antara kinerja lingkungan, ukuran perusahaan dan profitabilitas pada pengaruhnya terhadap pengungkapan emisi karbon. Dari hal tersebut didapat rumusan masalah dalam penelitian ini adalah apakah kinerja lingkungan, ukuran perusahaan dan profitabilitas berpengaruh pada pengungkapan emisi karbon.

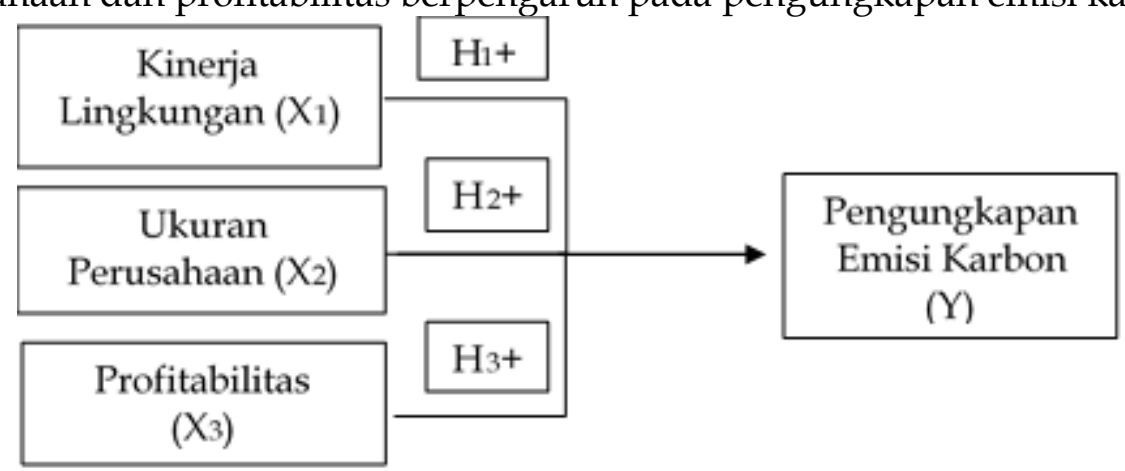

\section{Gambar 1. Model Penelitian}

Sumber: Data Penelitian, 2020

Tujuan penelitian yaitu untuk membuktikan secara empiris pengaruh kinerja lingkungan, ukuran perusahaan dan profitabilitas pada pengungkapan emisi kaarbon. Manfaat penelitian secara teoritis adalah dapat memberikan kontribusi dalam kajian empiris terkait dengan teori legitimasi dan teori stakeholder, serta dapat dijadikan pengembangan, perbandingan dan penyempurnaan dari penelitian yang telah dilakukan sebelumnya mengenai pengaruh kinerja lingkungan, ukuran perusahaan dan profitabilitas pada pengungkapan emisi karbon. Sedangkan manfaat praktis penelitian ini adalah untuk perusahaan penelitian ini dapat memberikan tambahan informasi untuk bahan pertimbangan dalam pengambilan keputusan dalam hal pelaporan pengungkapan emisi karbon dan lebih meningkatkan kesadaran dalam mengelola perusahaan yang lebih mengedepankan kelestarian lingkungan. Bagi masyarakat, investor dan calon investor penelitian ini dapat memberikan 
informasi tambahan dalam pengambilan keputusan berinvestasi. Bagi pemerintah penelitian ini dapat memberikan tambahan informasi untuk dijadikan pertimbangan dalam penetapan regulasi khususnya dalam hal pengungkapan emisi karbon.

Adanya teori legitimamsi mengharuskan perusahaan untuk melakukan pelestarian lingkungan dengan melakukan kinerja lingkungan. Perusahaan yang melakukan kinerja lingkungan yang baik akan memiliki strategi lingkungan yang proaktif sehingga mendorong perusahaan untuk melaporkan pengungkapan lingkungannya dalam pengungkapan emisi karbon kepada investor dan stakeholder untuk mendapatkan legitimasi. Jika kinerja lingkungan perusahaan baik maka cenderung perusahaan akan melakukan lebih banyak pengungkapan emisi karbon. Hal tersebut sejalan dengan penelitian yang dilakukan oleh (Clarkson, et al.., 2008), (Dawkins dan Fraas, 2011), (Matsumura, et al., 2014). Sehingga hipotesis pertama dalam penelitia ini adalah sebagai berikut.

$\mathrm{H}_{1}$ : Kinerja lingkungan berpengaruh pada pengungkapan emisi karbon.

Semakin besar ukuran perusahaan maka akan mendapat perhatian yang lebih besar pula dari masyarakat. Perusahaan yang besar lebih banyak melakukan aktivitas yang memiliki dampak lebih banyak terhadap lingkungan sehingga perusahaan mendapat tekanan dari masyarakat untuk melakukan lebih banyak aktivitas dalam hal menjaga kelestarian lingkungan salah satunya yaitu dengan melakukan pengungkapan emisi karbon. Perusahaan besar akan cenderung melakukan lebih banyak pengungkapan emisi karbon agar mendapat legitimasi dari masyarakat. Berdasarkan teori stakeholder menyatakan adanya interaksi perusahaan besar dengan masyarakat yang cenderung lebih banyak dan berpengaruh signifikan secara ekonomi, dan organisasi perusahaan besar lebih terlihat oleh media, pembuat kebijakan, regulator dan masyarakat. Hal tersebut didukung oleh hasil penelitian yang dilakukan oleh (Pradini dan Kiswara, 2013), (Prafitri dan Zulaikha, 2016), (Wang, et al., 2013) sehingga hipotesis kedua penelitian ini adalah sebagai berikut.

$\mathrm{H}_{2}$ : Ukuran perusahaan berpengaruh pada pengungkapan emisi karbon.

Perusahaan dengan kondisi keuangan yang baik akan mampu membayar sumber daya manusia dan mesin tambahan yang dibutuhkan untuk melakukan pengungkapan emisi karbon yang tinggi untuk menahan tekanan eksternal. Sebaliknya perusahaan yang memiliki keuangan yang rendah cenderung lebih fokus untuk pencapaian tujuan dalam hal keuangan dan peningkatan kinerja keuangan mereka sehingga membatasi kemampuannya dalam upaya pengungkapan emisi karbon. Hal tersebut sejalan dengan hasil penelitian yang dilakukan oleh (Cahya, 2016), (Jannah dan Muid, 2014) sehingga hipotesis ketiga penelitian ini adalah sebagai berikut.

$\mathrm{H}_{3}$ : Profitabilitas berpengaruh positif pada pengungkapan emisi karbon.

\section{METODE PENELITIAN}

Penelitian ini menggunakan pendekatan kuantitatif yang berbentuk asosiatif yang dilakukan pada perusahaan non keuangan yang terdaftar di Bursa Efek Indonesia (BEI) pada tahun 2017 dan 2018 yang diakses melalui situr resmi BEI yaitu Indonesia Stock Exchange (IDX). Alasan penelitian ini dilakukan pada 
perusahaan non keuangan karena pada perusahaan non keuangan dalam melakukan aktivitas operasional perusahaannya paling banyak menghasilkan emisi karbon dan lebih banyak mempunyai dampak atau pengaruh terhadap lingkungan disekitarnya.

Objek penelitin dalam penelitian ini adalah pengungkapan emisi karbon yang diprediksi dengan kinerja lingkungan, ukuran perusahaan dan profitabilitas pada perusahaan non keuangan yang terdaftar di Bursa Efek Indonesia pada tahun 2017 dan 2018. Jenis data yang digunakan adalah data kuantitatif berupa laporan tahunan yang berhubungan dengan variabel dalam penelitian ini yaitu total aset, laba bersih setelah pajak, pengungkapan emisi karbon dan PROPER. Sumber data penelitian adalah data sekunder berupa laporan tahunan perusahaan non keuangan yang diperoleh dari situs resmi BEI dan pringkat PROPER yang diperoleh dari situs resmi Kementerian Lingkungan Hidup dan Kehutanan.

Populasi dalam penelitian ini adalah seluruh perusahaan non keuangan yang terdaftar di Bursa Efek Indonesia dan sampel penelitian yang digunakan adalah perusahaan yang terdaftar di Bursa Efek Indonesia pada tahun 2017 dan 2018. Metode penentuan sampel yang digunakan adalah metode nonprobability sampling dengan teknik purposive sampling. Adapun kriteria penentuan sampel yang digunakan penelitian ini yaitu perusahaan non keuangan yang terdaftar di BEI yang menerbitkan laporan tahunan dan mendapat PROPER selama tahun 2017 dan 2018. Pengungkapan emisi karbon diukur dengan menggunakan indeks pengungkapan yang dikembangkan oleh Choi et al., (2013). Jumlah indeks pengungkapan yang digunakan yaitu 18 item, sehingga setiap item yang diungkapkan perusahaan akan dijumlahkan kemudian dibagi dengan jumlah item pengungkapan emisi karbon. Kinerja lingkungan diproksikan dengan tingkat PROPER yang didapat perusahaan, PROPER dibagi menjadi lima warna dan setiap warna akan diberi skor. Ukuran perusahaan diukur dengan logaritma natural total asset perusahaan. Profitabilitas akan dikur dengan menggunakan rasio return on asset. Data penelitian dianalisis menggunakan analisis regresi linier berganda. Sebelum model regresi digunakan untuk menguji hipotesis, terlebih dahulu dilakukan pengujian asumsi klasik. Model analisis regresi linier berganda yang digunakan dalam penelitian ini adalah sebagai berikut.

$Y=\alpha+\beta 1 X 1+\beta 2 X 2+\beta 3 X 3+\varepsilon$

Keterangan:

$\mathrm{Y} \quad=$ Pengungkapan emisi karbon

$\mathrm{a} \quad=$ Nilai konstanta

$\beta 1=$ Koefisien regresi dari kinerja lingkungan

$\beta 2=$ Koefisien regresi dari ukuran perusahaan

$\beta 3=$ Koefisien regresi dari profitabilitas

$\mathrm{X} 1=$ Kinerja Lingkungan

$\mathrm{X} 2=$ Ukuran Perusahaan

$\mathrm{X} 3=$ Profitabilitas

$\varepsilon=$ Standar eror 


\section{HASIL DAN PEMBAHASAN}

Penelitian ini dilakukan pada perusahaan non keuangan yang terdaftar di Bursa Efek Indonesia pada tahun 2017 dan 2018. Data penelitian diperoleh melalui situs resmi BEI dan Kementerian Lingkungan Hidup dan Kehutanan. Metode penentuan sampel yang digunakan adalah metode nonprobability sampling dengan teknik purposive sampling dan diperoleh 64 perusahaan dengan 2 tahun periode pengamatan, sehingga jumlah sampel dalam periode pengamatan adalah sebanyak 128 sampel penelitian, namun adanya data outlier yang menyebabkan 16 sampel dikeluarkan karena terdapat masalah normalitas residual sehingga total sampel penelitian menjadi 112 perusahaan observasi. Hasil analisis statistik deskriptif dalam penelitian ini disajikan pada Tabel 2.

Tabel 2. Statistik Deskriptif

\begin{tabular}{llllll}
\hline & $\mathrm{N}$ & Minimum & Maximum & Mean & Std. Deviation \\
\hline X1 & 112 & 2 & 4 & 2,964 & 0,401 \\
X2 & 112 & 13,151 & 18,571 & 15,612 & 1,369 \\
X3 & 112 & $-0,316$ & 0,466 & 0,052 & 0,094 \\
Y & 112 & 0,000 & 0,778 & 0,219 & 0,146 \\
Valid N (listwise) & 112 & & & &
\end{tabular}

Sumber: Data penelitian, 2020

Nilai minimum variabel pengungkapan emisi karbon sebesar 0,000 yang dimiliki oleh PT Garuda Metalindo Tbk (BOLD), PT Surya Esa Perkasa Tbk(ESSA), PT Eagle High Plantations Tbk (BWPT), PT Sumi Indo Kabel Tbk (IKBI), PT Indospring Tbk (INDS), PT Tifico Fiber Indonesia Tbk (TFCO) pada tahun 2017 dan PT Garuda Metalindo Tbk (BOLD), PT Surya Esa Perkasa Tbk (ESSA), PT Eagle High Plantations Tbk (BWPT), PT Agro Pantes Tbk (ARGO), PT Melindo Feedmill Tbk (MAIN) pada tahun 2018. Nilai maksimumnya sebesar 0,778 yang dimiliki oleh PT Unilever Tbk (UNVR) pada tahun 2018. Nilai mean sebesar 0,219 yang menunjukkan bahwa rata-rata perusahaan mengungkapkan emisi karbon sebesar 0,219 atau sebesar 3 hingga 4 item dari total 18 item pengungkapan emisi kabon dan cenderung mendekati nilai minimum yang menunjukkan bahwa pengungkapan emisi karbon yang dilakukan oleh perusahaan non keuangan yang terdaftar di BEI tergolong kurang baik. Nilai deviasi standar untuk nilai pengungkapan emisi karbon sebesar 0,146 yang menunjukkan bahwa terjadi perbedaan nilai pengungkapan emisi karbon terhadap nilai sata-ratanya sebesar 0,146 persen.

Nilai minimum variabel kinerja lingkungan sebesar 2 yang dimiliki oleh PT Goodyear Indonesia Tbk (GDYR), PT Sumi Indo Kabel Tbk (IKBI), PT KMI Wire \& Cable Tbk (KBLI), PT Martina Berto Tbk (MBTO), dan PT Sri Rejeki Isman Tbk (SRIL) pada tahun 2017 dan PT Gajah Tunggal Tbk (GJTL), PT Sumi Indo Kabel Tbk (IKBI), PT KMI Wire \& Cable Tbk (KBLI), PT Kabelindo Murni Tbk (Kblm), PT P Lippo Cikarang Tbk (LPCK), PT Martina Berto Tbk (MBTO) dan PT United Tractors Tbk (UNTR) pada tahun 2018. Nilai Maksimum sebesar 4 yang dimilikioleh PT Aneka Tambang Tbk (ANTM), PT Indofood CBP Sukses Makmur Tbk (ICBP), PT Phapros Tbk (PEHA) PT Industri Jamu dan Farmasi Sido Tbk (SIDO) pada tahun 2017 dan PT Aneka Tambang Tbk (ANTM) da PT Indofood CBP Sukses Makmur Tbk (ICBP) pada tahun 2018. Nilai mean sebesar 2,964 yang menunjukkan bahwa rata-rata perusahaan mendapat PROPER pada 
tingkat 3 atau warna biru. Nilai deviasi standar sebesar 0,401 yang menunjukkan bahwa terjadi perbedaan nilai kinerja lingkungan terhadap nilai rata-ratanya sebesar 0,401 persen.

Nilai minimum variabel ukuran perusahaan sebesar 13,151 yang dimiliki oleh PT Trisula Textile Industries Tbk (BELL) pada tahun 2018. Nilai maksimumnya sebesar 18,571 yang dimiliki oleh PT United Tractors Tbk (UNTR) pada tahun 2018. Nilai mean sebesar 15,612 yang menunjukkan bahwa rata-rata perusahaan yang menjadi sampel penelitian memiliki ukuran yang cukup besar. Nilai deviasi standar sebesar 1,369 yang menunjukkan bahwa terjadi perbedaan nilai ukuran perusahaan terhadap nilai rata-ratanya sebesar 1,369 persen.

Nilai minimum variabel profitabilitas sebesar $-0,104$ yang dimiliki oleh PT Matina Berto Tbk (MBTO) pada tahun 2017. Nilai maksimumnya sebesar 0,466 yang dimiliki oleh PT Unilever Indonesia Tbk (UNVR) pada tahun 2018. Nilai mean untuk variabel profitabilitas sebesar 0,052 . Nilai deviasi standar sebesar 0,094 yang menunjukkan bahwa terjadi perbedaan nilai profitabilitas terhadap nilai rata-ratanya sebesar 0,094 persen

Sebelum melakukan analisis regresi linear berganda terlebih dahulu dilakukan uji asumsi klasik. Uji yang pertama yaitu uji normalitas yang betujuan untuk mengetahui data yang digunakan dalam penelitian ini berdistribusi normal atau tidak. Uji normalitas dalam penelitian ini menggunakan Uji Kolmogorov-Smirnow (K-S). Jika Asymp.Sig. (2-tailed) $>a=0,05$ maka data penelitian yang digunakan menunjukkan telah berdistribusi normal. Berikut merupakan hasil uji normalitas dalam penelitian ini yang ditunjukkan pada Tabel 3.

Tabel 3. Hasil Uji Normalitas

\begin{tabular}{llc}
\hline $\mathrm{N}$ & & Unstandardized Residual \\
Normal Parameters, $\mathrm{b}$ & Mean & 112 \\
& Std. Deviation & $0 \mathrm{E}-7$ \\
& Absolute & 0,13559575 \\
Most Extreme Differences & Positive & 0,95 \\
& Negative & 0,95 \\
Kolmogorov-Smirnov Z & & $-0,040$ \\
Asymp. Sig. (2-tailed) & & 1,011 \\
\hline
\end{tabular}

Sumber: Data penelitian, 2020

Berdasarkan Tabel 3, menunjukkan hasil Kolmogorov-Smirnow bahwa nilai Asymp.Sig. (2-tailed) sebesar 0,259. Hasil tersebut lebih besar dari 0,05 sehingga dapat disimpulkan bahwa data yang digunakan dalam penelitian ini telah berdistribusi normal.

Uji yang kedua yaitu uji multikolinearitas yang bertujuan untuk menguji model regresi yang digunakan dalam penelitian ini ada korelasi antar variabel bebas atau tidak (Ghozali, 2016:103). Deteksi yang digunakan dalam uji multikolinearitas yaitu dengan melihat nilai Tolerance dan VIF. Kriteria yang digunakan yaitu jika nilai Tolerance $>0,1$ menunjukkan bahwa tidak terdapat gejala multikolinearitas pada model regresi yang digunakan. Jika nilai VIF $<10$ menunjukkan bahwa tidak ada gejala multikolinearitas pada model regresi. Hasil uji multikolinearitas pada penelitian ini ditunjukkan pada Tabel 4. 
Tabel 4. Hasil Uji Multikolienaritas

\begin{tabular}{lcc}
\hline Model & \multicolumn{2}{c}{ Collinearity Statistics } \\
\cline { 2 - 3 } & Tolerance & VIF \\
\hline Constant $)$ & & \\
X1 & 0,925 & 1,081 \\
X2 & 0,863 & 1,159 \\
X3 & 0,920 & 1,087 \\
\hline
\end{tabular}

Sumber: Data penelitian, 2020

Berdasarkan Tabel 4, menunjukkan nilai Tolerance dari semua variabel bebas yang digunakan pada penelitian bernilai lebih dari 0,1 dan semua nilai VIF variabel bebas yag digunakan pada penelitian ini menunjukkan nilai kurang dari 10. Sehingga dapat disimpulkan bahwa semua variabel bebas yang digunakan pada penelitian ini terbebas dari gejala multikolinearitas.

Uji yang ketiga yaitu uji heteroskedastisitas yang bertujuan untuk mengukur sama atau tidaknya varian dari residual observasi satu dengan observasi lainnya. Kriteria yang digunakan dalam uji heteroskedastisitas yaitu jika nilai sig variabel bebas $>0,05$ maka menunjukkan bahwa tidak terjadi heterokedastisitas pada penelitian ini. Namun jika nilai sig variabel bebas $<0,05$ maka menunjukkan terjadi heteroskedastisitas pada penelitian. Hasil uji heteroskedastisitas dapat dilihat pada Tabel 5.

Tabel 5. Hasil Uji Heteroskedastisitas

\begin{tabular}{|c|c|c|c|c|c|c|}
\hline \multirow{2}{*}{\multicolumn{2}{|c|}{ Model }} & \multicolumn{2}{|c|}{ Unstandardized Coefficients } & Standardized & \multirow[t]{2}{*}{$t$} & \multirow[t]{2}{*}{ Sig. } \\
\hline & & B & Std. Error & Beta & & \\
\hline \multirow{4}{*}{1} & (Constant) & $-0,151$ & 0,102 & & $-1,485$ & 0,141 \\
\hline & X1 & 0,022 & 0,021 & 0,104 & 1,072 & 0,286 \\
\hline & $\mathrm{X} 2$ & 0,012 & 0,006 & 0,194 & 1,924 & 0,057 \\
\hline & X3 & 0,022 & 0,089 & $-0,024$ & 0,251 & 0,802 \\
\hline
\end{tabular}

Sumber: Data penelitian, 2020

Bedasarkan Tabel 5, menunjukkan nilai signifikansi semua variabel bebas dalam penelitian ini lebih dari 0,05, sehingga dapat disimpulkan bahwa tidak terdapat gejala heteroskedastisitas pada model regresi penelitian ini.

Uji yang keempat yaitu uji autokorelasi yang bertujuan untuk mengetahui apakah terjadi korelasi dari suatu periode $t$ dengan periode sebelumnya (t-1). Untuk mengetahui hasil uji autokorelasi pada penelitian ini digunakan metode Durbin Watson (DW Test) (Ghozali, 2016:107). Uji Durbin Watson merupakan salah satu alat uji yang digunakan untuk mengetahui apakah suatu model regresi terdapat autokorelasi atau tidak. Kriteria penilaian untuk melihat nilai Durbin Watson yaitu jika dU $<\mathrm{dw}<4$-dU, maka tidak terjadi autokorelasi. Hasil uji autokorelasi dengan menggunakan metode Durbin Watson dapat dilihat pada Tabel 6 .

\section{Tabel 6. Hasil Uji Autokorelasi}

\begin{tabular}{lllllc}
\hline Model & $\mathrm{R}$ & $\mathrm{R}$ Square & $\begin{array}{c}\text { Adjusted R Square Std. Error of the } \\
\text { Estimate }\end{array}$ & Durbin-Watson \\
\hline 1 & $0,380^{\mathrm{a}}$ & 0,144 & 0,121 & 0,1374661 & 2,151 \\
\hline
\end{tabular}

Sumber: Data penelitian, 2020

Berdasarkan Tabel 6, menunjukkan bahwa nilai DW sebesar 2,151. Dalam tabel Durbin Watson dengan taraf signifikan 5 persen, jumlah sampel 112 dan 
banyak variabel bebas (k) adalah 3, maka diperoleh nilai $\mathrm{dL}$ sebesar 1,6373 dan nilai dU sebesar 1,7472. Dengan demikian diperoleh hasil uji autokorelasi yaitu $1,7472<2,151<2,2528$. Sesuai kriteria uji Durbin Watson, maka dapat disimpulkan bahwa tidak terdapat gejala autokorelasi daam penelitian ini.

Setelah melakukan uji asumsi klasik maka dapat dilakukan analisis regresi linear berganda. Hasil dari analisis regresi linear berganda pada penelitian ini dapat dilihat pada Tabel 7.

Tabel 7. Hasil Analisis Regresi Linear Berganda

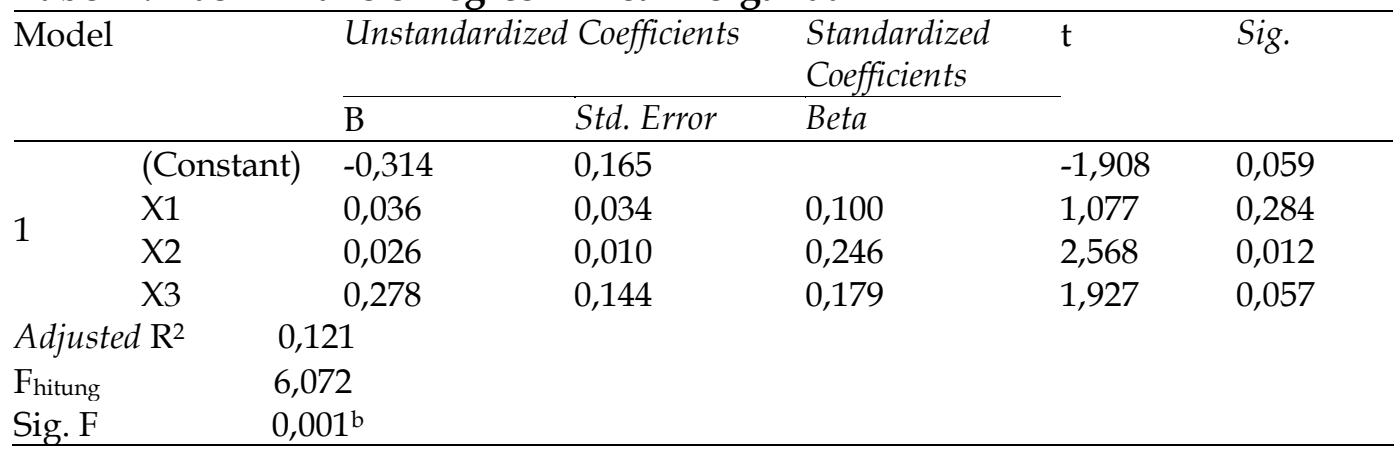

Sumber: Data penelitian, 2020

Berdasarkan Tabel 7, diperoleh model analisis regresi linear berganda yang digunakan untuk penelitian ini adalah sebagai berikut.

$$
\mathrm{Y}=-0,314+0,036 \mathrm{X}_{1}+0,026 \mathrm{X}_{2}+0,278 \mathrm{X}_{3}
$$

Nilai konstan sebesar $-0,314$ yang menunjukkan bahwa jika kinerja lingkungan, ukuran perusahaan dan profitabilitas diasumsikan bernilai nol, maka pengungkapan emisi karbon akan sebesar 0,314. Nilai koefisien regresi variabel kinerja lingkungan menunjukkan nilai sebesar 0,036. Koefisien regresi tersebut memiliki nilai positif yang menunjukkan bahwa apabila kinerja lingkungan meningkat sebesar satu persen maka pengungkapan emisi karbon akan meningkat sebesar 0,036 dengan asumsi variabel lainnya adalah konstan. Nilai koefisien regresi variabel ukuran perusahaan menunjukkan nilai sebesar 0,026. Koefisien tersebut memiliki nilai positif yang menunjukkan bahwa apabila ukuran perusahaan meningkat sebesar satu persen maka pengungkapan emisi karbon akan meningkat sebesar 0,026 dengan asumsi variabel lainnya adalah konstan. Nilai koefisien regresi variabel profitabilitas menunjukkan sebesar 0,278 . Koefisien tersebut memiliki nilai positif yang menunjukkan bahwa apabila profitabilitas meningkat sebesar satu persen maka pengungkapan emisi karbon akan meningkat sebesar 0,278 dengan asumsi variabel lainnya adalah konstan.

Nilai adjusted $R^{2}$ adalah sebesar 0,121 yang menunjukkan bahwa 12,1 persen dari variansi pengungkapan emisi karbon pada perusahaan non keuangan yang terdaftar di Bursa Efek Indonesia tahun 2017 dan 2018 dijelaskan oleh variabel yang ada di dalam penelitian ini yaitu kinerja lingkungan, ukuran perusahaan dan profitabilitas sedangkan sisanya sebesar 87,9 persen dipengaruhi oleh faktor-faktor lain yang tidak dimasukkan dalam model regresi. Nilai $F_{\text {hitung }}$ sebesar 6,072 dengan nilai signifikansi F sebesar 0,001. Nilai signifikansi F tersebut lebih kecil dari level signifikansi 0,05 , sehingga model penelitin ini layak digunakan.

Nilai $p$-value untuk variabel kinerja lingkungan adalah sebesar 0,284 $>a=$ 0,05 dengan nilai koefisien sebesar 0,036. Berdasarkan hal tersebut menunjukkan 
bahwa kinerja lingkungan tidak berpengaruh signifikan pada pengungkapan emisi karbon, sehingga dapat disimpulkan hipotesis pertama dalam penelitian ini ditolak.

Nilai $p$-value untuk variabel ukuran perusahaan adalah sebesar 0,012 < a $=0,05$ dengan nilai koefisien regresi sebesar 0,026. Berdasarkan hal tersebut menunjukkan bahwa ukuran perusahaan berpengaruh signifikan pada pengungkapan emisi karbon, sehingga dapat disimpulkan hipotesis kedua dalam penelitian ini diterima.

Nilai $p$-value untuk variabel profitabilitas adalah sebesar 0,057> $\alpha=0,05$ dengan nilai koefisien regresi sebesar 0,278. Berdasarkan hal tersebut menunjukkan bahwa profitabilitas tidak berpengaruh signifikan pada pengungkapan emisi karbon, sehingga dapat disimpulkan hipotesis ketiga dalam penelitian ini ditolak.

Hipotesis pertama menyatakan kinerja lingkungan berpengaruh positif pada pengungkapan emisi karbon. Hasil analisis menunjukkan kinerja lingkungan tidak berpengaruh pada pengungkapan emisi karbon. Berdasarkan hal tersebut menunjukkan bahwa kinerja lingkungan yang diproksikan dengan PROPER tidak berpengaruh pada pengungkapan emisi karbon, sehingga hipotesis pertama dalam penelitian ini ditolak.

Teori legitimasi menyatakan perusahaan akan selalu berusaha untuk mentaati norma yang berlaku dalam masyarakat agar mendapat legitimasi, perusahaan yang mendapat PROPER tinggi merasa tidak perlu melakukan pengungkapan emisi karbon karena mereka menganggap bahwa upaya mereka dalam menurunkan emisi karbon sudah terlihat dari PROPER yang didapat sehingga tidak lagi perlu melakukan pengungkapan emisi karbon untuk mendapat legitimasi dari masyarakat. Sebaliknya perusahaan yang mendapat PROPER yang rendah cenderung akan melakukan lebih banyak pengungkapan emisi karbon untuk mendapat legitimasi. Hasil penelitian ini didukung oleh hasil penelitian yang dilakukan oleh (Apriliana, 2019), (Suhardi, et al., 2015), (Akhiroh \& Kiswanto, 2016).

Hipotesis kedua menyatakan ukuran perusahaan berpengaruh positif pada pengungkapan emisi karbon. Hasil analisis menunjukkan ukuran perusahaan berpengaruh pada pengungkapan emisi karbon. Arah koefisien ukuran perusahaan dalam penelitian bertanda positif, berdasarkan hal tersebut menunjukkan bahwa semakin besar ukuran perusahaan maka pengungkapan emisi karbon yang dilakukan akan semakin besar pula, sehingga hipotesis kedua penelitian ini diterima.

Penelitian ini mendukung teori legitimasi yang menyatakan perusahaan dalam menjalankan aktivitas-aktivitas operasionalnya akan selalu berusaha untuk mentaati norma yang dapat diterima oleh masyarakat, salah satunya dengan melakukan pengungkapan emisi karbon sebagai upaya perusahaan untuk memperoleh legitimasi. Semakin besar ukuran perusahaan maka perhatian mayarakat terhadap perusahaan tersebut akan semakin besar pula, hal tersebut terjadi karena perusahan yang besar lebih mempunyai dampak yang lebih banyak terhadap lingkungan akibat dari aktivitas operasional perusahaan sehingga perusahaan mendapat tekanan untuk melakukan lebih banyak pengungkapan emisi karbon. Berdasarkan hal tersebut perusahaan besar akan 
cederung lebih banyak melakukan pengungkapan emisi karbon dibandingkan dengan perusahaan kecil.

Berdasarkan teori stakeholder interaksi perusahaan besar dengan masyarakat cenderung lebih banyak dan memiliki pengaruh signifikan secara ekonomi. Selain itu organisasi perusahaan besar lebih terlihat oleh media, pemerintah dan pembuat kebijakan yang membuat perusahaan mendapat tekanan dari banyak pihak untuk melakukan pengungkapan emisi karbon. Para stakeholder juga ingin perusahaannya dipandang baik oleh masyarakat agar mendapatkan legitimasi sehingga perusahaan besar akan lebih banyak melakukan pengungkapan emisi karbon. Hasil penelitian ini sejalan dengan hasil penelitian yang dilakukan oleh (Selviana \& Ratmono, 2019), (Prafitri \& Zulaikha, 2016), (Wang, et al.., 2013), (Muljiani, et al., 2019), (Kurniawati \& Biduri, 2018).

Hipotesis ketiga menyatakan profitabilitas berpengaruh positif pada pengungkapan emisi karbon. Hasil analisis menunjukkan profitabilitas tidak berpengaruh pada pengungkapan emisi karbon. Berdasarkan hal tersebut menunjukkan bahwa besar kecilnya profitabilitas perusahaan tidak berpengaruh pada pengungkapan emisi karbon, sehingga hipotesis ketiga penelitian ini ditolak.

Kinerja keuangan suatu perusahaan yang baik tidak selalu dapat dijadikan pertimbangan dalam melakukan pengungkapan emisi karbon. Hal tersebut terjadi karena ketika perusahaan memiliki tingkat laba yang tinggi perusahaan akan menganggap tidak perlu melakukan atau melaporkan kegiatan yang dapat mengganggu informasi mengenai keuangan perusahaan. Kemudian Pradini \& Kiswara (2013) menyatakan perusahaan dengan tingkat profitabilitas yang rendah justru mengambil keuntungan dari pengungkapan lingkungan untuk mendapat legitimasti. Sebaliknya, perusahaan dengan profitabilitas yang tinggi merasa untuk tidak perlu melakukan perluasan pengungkapan emisi karbon karena mereka takut bahwa pengungkapan tersebut dapat menganggu informasi keberhasilan keuangan perusahaan. Hasil penelitian ini sejalan dengan penelitian yang dilakukan oleh (Pratiwi, 2018) dan (Selviana \& Ratmono, 2019).

\section{SIMPULAN}

Berdasarkan hasil analisis dan pembahasan penelitian yang dilakukan pada perusahaan non keuangan yang terdaftar di BEI tahun 2017 dan 2018, maka dapat disimpulkan, kinerja lingkungan tidak berpengaruh pada pengungkapan emisi karbon. Tinggi atau rendahnya peringkat PROPER yang didapat tidak berpengaruh pada pengungkapan emisi karbon yang dilakukan oleh perusahaan. Ukuran perusahaan berpengaruh positif pada pengungkapan emisi karbon. Semakin besar ukuran perusahaan maka perusahaan akan melakukan semakin banyak pengungkapan emisi karbon. Profitabilitas tidak berpengaruh dalam pengungkapan emisi karbon. Tinggi atau rendahnya profitabilitas perusahaan tidak mampu mempengaruhi pengungkapan emisi karbon.

Keterbatasan penelitian ini adalah keterbatasan dalam proksi kinerja lingkungan yang hanya menggunakan tingkat PROPER. Peneliti selanjutnya disarankan tidak hanya menggunakan PROPER tetapi juga menggunakan sertifikat ISO agar dapat mewakili keseluruhan penerapan kinerja lingkungan pada suatu perusahaan. Peneliti selanjutnya dapat menambah variabel bebas lain 
dalam pengaruhnya pada pengungkapan emisi karbon. Saran untuk variabel lain yang bisa digunakan yaitu tipe industry, karena perusahaan yang termasuk high profil dalam menjalankan aktivitasnya akan lebih banyak menggunakan sumber daya dan cenderung akan berdampak lebih besar pada lingkungan sehingga mendapat tekanan dari masyarakat untuk melakukan lebih banyak pengungkapan emisi karbon. Kemudian saran variabel lain yang bisa digunakan yaitu kepemilikan institusional. Kepemilikan institusional merupakan pihak yang dapat memonitoring atau mengawasi jalannya perusahaan karena bersifat independen. Adanya kepemilikan institusional di dalam perusahaan mengharuskan perusahaan untuk menyelaraskan diri dengan lingkungan dan sosial di sekitar perusahaan karena investor institusional biasanya lebih memilih untuk berinvestasi dalam perusahaan yang memiliki pencapaian sosial yang baik daripada perusahaan dengan kinerja sosial yang buruk, sehingga besarnya tingkat kepemilikan institusional di dalam perusahaan dapat mendorong perusahaan untuk lebih banyak mengungkapkan informasi mengenai pengungkapan emisi karbon. Selain itu diharapkan mengembangkan indeks pengungkapan emisi karbon yang digunakan untuk mengukur luas pengungkapan emisi karbon yang sesuai dengan kondisi yang ada di Indonesia, karena dalam penelitian ini pengukuran yang digunakan untuk menilai pengungkapan emisi karbon peneliti mengadopsi dari penelitian Choi et al., 2013).

\section{REFERENSI}

Akhiroh, T., \& Kiswanto. (2016). The Determinant Of Carbon Emission Disclosures. Accounting Analysis Journal, 5(4), 326-336. https://doi.org/10.15294/aaj.v5i4.11182

Apriliana, E. (2019). Pengaruh Tipe Industri, Kinerja Lingkungan, Dan Profitabilitas Terhadap Carbon Emission Disclosure. Widyakala Journal, 6(1), 84. https://doi.org/10.36262/widyakala.v6i1.149

Cahya, B. T. (2016). Carbon Emission Disclosure: Ditinjau Dari Media Exposure, Kinerja Lingkungan Dan Karakteristik Perusahaan Go Public Berbasis Syariah Di Indonesia. 06.

Choi bo bae, Lee, D., \& Psaros, J. (2013). An analysis of Australian company carbon emission disclosures. Pacific Accounting Review, 25(1), 58-79. https://doi.org/10.1108/01140581311318968

Clarkson, P. M., Li, Y., Richardson, G. D., \& Vasvari, F. P. (2008). Revisiting the relation between environmental performance and environmental disclosure: An empirical analysis. Accounting, Organizations and Society, 33(4-5), 303327. https://doi.org/10.1016/j.aos.2007.05.003

CNN Indonesia. (2019). Laporan Perubahan Iklim PBB: 2019 jadi Tahun Terpanas. CNN IIndoensia. Retrieved from https://www.cnnindonesia.com/teknologi/20190923121304-199432939/laporan-perubahan-iklim-pbb-2019-jadi-tahun-terpanas

Dawkins, C., \& Fraas, J. W. (2011). Coming Clean: The Impact of Environmental Performance and Visibility on Corporate Climate Change Disclosure. Journal of Business Ethics, 100(2), 303-322. https:/ / doi.org/10.1007/s10551-010-06810 
Ghozali, I. (2016). Aplikasi Analisis Multivariate dengan Program IBM SPSS 21 :Update PLS Regresi. In Semarang: Badan Penerbit Universitas Diponegoro. https://doi.org/10.2307/1579941

Ghozali, Imam. (2016). Aplikasi Analisis Multivariete Dengan Program IBM SPSS 23 (Edisi 8) (VIII). Semarang: Badan Penerbit Universitas Diponegoro.

Guthrie, J., \& Parker, L. D. (1989). Corporate Social Reporting: A Rebuttal of Legitimacy Theory. Accounting and Business Research, 19(76), 343-352. https://doi.org/10.1080/00014788.1989.9728863

Jannah, R., \& Muid, D. (2014). Analisis Faktor-Faktor Yang Mempengaruhi Carbon Emission Disclosure Pada Perusahaan Di Indonesia (Studi Empiris pada Perusahaan yang Terdaftar di Bursa Efek Indonesia Periode 2010-2012). 3(2), 1000-1010.

Kehutanan, K. L. H. dan. (2017). Hasil Penilaian Peringkat Kinerja Perusahaan Dalam Pengelolaan Lingkungan Hidup Tahun 2016 - 2017.

Kehutanan, K. L. H. dan. (2018). Hasil Penilaian Peringkat Kinerja Perusahaan Dalam Pengelolaan Lingkungan Hidup Tahun 2017 - 2018.

Kementerian Lingkungan Hidup dan Kehutanan. (2018). Indonesia Telah Berhasil Turunkan Emisi Karbon 8,7\% dari Target 29\%. Retrieved from http://ppid.menlhk.go.id/siaran_pers/browse/1357

Kementrian Lingkungan Hidup dan Kehutanan. (2019). Statistik Tahun 2018 Direktorat Jendral Perubahan Iklim. 75-76. Retrieved from http://ditjenppi.menlhk.go.id/reddplus/images/adminppi/dokumen/stat istik_PPI_2018_opt.pdf

Kurniawati, \& Biduri, S. (2018). Apakah Ukuran Perusahaan, Media Exposure dan Profitability Berpengaruh Terhadap Carbon Emission Disclosure. Seminar Nasional Dan The 5th Call for Syariah Paper.

Matsumura, E. M., Prakash, R., \& Vera-Muñoz, S. C. (2014). Firm-value effects of carbon emissions and carbon disclosures. Accounting Review, 89(2), 695-724. https://doi.org/10.2308/accr-50629

Muljiani, S., Juardi, \& Feni. (2019). Determinan Carbon Emission Disclosure Pada Perusahaan Bumn Yang Terdaftar Di Bursa Efek Indonesia Periode 20132017. Journal of Chemical Information and Modeling, 53(9), 1689-1699. https://doi.org/10.1017/CBO9781107415324.004

Peraturan Menteri Lingkungan Hidup Nomor 03 Tahun 2014 Tentang Program Penilaian Peringkat Kinerja Perusahaan dalam Pengelolaan Lingkungan Hidup.

Perpres No. 61 tahun 2011 mengenai Rencana Aksi Nasional Penurunan Emisi Gas Rumah Kaca.

Perpres No. 71 tahun 2011 mengenai Penyelenggaraan Inventasrisasi Gas Rumah Kaca Nasional.

Pradini, H. S., \& Kiswara, E. (2013). The Analysis of Information Content towards Greenhouse Gas Emissions Disclosure In Indonesia's Companies. 2(2011), 736747.

Prafitri, A., \& Zulaikha, Z. (2016). Analisis Pengungkapan Emisi Gas Rumah Kaca. Jurnal Akuntansi \& Auditing, 13(2), 155-175. https://doi.org/https://doi.org/10.14710/jaa.13.2.155-175

Pratiwi, D. N. (2018). Implementasi Carbon Emission Disclosure di Indonesia. 
Jurnal Ilmiah Akuntansi Dan Bisnis, (2007), 101. https://doi.org/10.24843/JIAB.2018.v13.i02.p04

Selviana, \& Ratmono. (2019). Pengaruh Kinerja Karbon, Karakteristik Perusahaan Dan Kinerja Lingkungan Terhadap Pengungkapan Emisi Karbon. 8(2017), 1-10.

Suhardi, R. P., Prof, J., \& Sh, S. (2015). Analisis Faktor - Faktor Yang Mempengaruhi Pengungkapan Emisi Karbon Di Indonesia(Studi Pada Perusahaan Yang Terdaftar di Bursa Efek Indonesia Periode 2010 -2013). 4(2), 836-848.

Undang-Undang Republik Indonesia Nomor 17 Tahun 2004 tentang Pengesahan Kyoto Protocol to the United Nations Framework Convention On Climate Change (Protokol Kyoto atas Konvensi Kerangka Kerja Perserikatan Bangsa-Bangsa tentang Perubahan Iklim).

United Nations (1997), "Kyoto Protocol to the United Nations Framework Convention on Climate Change", available at: http://unfccc.int/resource/docs/convk p/kpeng.pdf.

UU. No. 20 Tahun 2008. Tentang Usaha Mikro Kecil Menengah.

Laporan Tahunan Perusahaan yang terdaftar di Bursa Efek Indonesia Periode tahun 2017-1018. $w w w . i d x$.co.id.

Wang, Lin, S., \& Yao, S. (2013). The determinants of corporate social responsibility disclosure: Evidence from China. Journal of Applied Business Research, 29(6), 1833-1847. https://doi.org/10.19030/jabr.v29i6.8220 